Bioremediation of Alkane Hydrocarbons Using Bacterial Consortium

\title{
From Soil
}

\author{
Majid Nozari ${ }^{1}$, Mohammad Reza Samaei ${ }^{1,2,{ }^{*}}$, Mansooreh Dehghani ${ }^{1}$ and Ali Asghar Ebrahimi ${ }^{3}$ \\ ${ }^{1}$ Department of Environmental Health Engineering, School of Health, Shiraz University of Medical Sciences, Shiraz, Iran \\ ${ }^{2}$ Department of Environmental Health Engineering, Research Center for Health Sciences, School of Health, Shiraz University of Medical Sciences, Shiraz, Iran \\ ${ }^{3}$ Department of Environmental Health Engineering, Environmental Science and Technology Center, Shahid Sadoughi University of Medical Sciences, Yazd, Iran \\ "Corresponding author: Department of Environmental Health Engineering, School of Health, Shiraz University of Medical Sciences, Shiraz, Iran. Tel: +98-9177320737, Fax: \\ +98-7117260225, Email: mrsamaei@sums.ac.ir
}

Received 2017 January 24; Revised 2017 May 03; Accepted 2017 June 16.

\begin{abstract}
Background: Contamination of soil with organic pollutants is one of the most important environmental challenges. Bioremediation is a simple and economical method for treatment of hydrocarbon-contaminated soil.

Objectives: The purpose of this study was to investigate the simultaneous bioremediation of n-hexadecane and n-dodecane from soil in an S-SBR using two types of bacterial consortium isolated from oil contaminated soils and compost.

Methods: In this study, S-SBR reactor was used at a pilot scale. For polluting the soil, agricultural soil was used. The n-hexadecane and n-dodecane were analyzed with GC-FID. Two microbial consortiums type A (Acinetobacter radioresistence, Bacillus subtilis and Pseudomonas aeruginosa) and type B (Ochrobactrum oryzae, Bacillus sp. and Sphingomonas yanoikuyae) were used. Type A and B were isolated from soil and compost, respectively.

Results: Maximum simultaneous bioremediation of n-hexadecane (17.61\%) and n-dodecane (28.55\%) was done by consortium type A. The maximum simultaneous bioremediation of n-hexadecane and n-dodecane by consortium type B was $13.22 \%$ and $19.24 \%$, respectively.

Conclusions: The findings of this study showed the simultaneous bioremediation of $n$-hexadecane and n-dodecane in an S-SBR using two types of the bacterial consortium (type A and B) during a three-day period was relatively satisfactory. Hydrocarbon removal by bacteria isolated from polluted soils was more than bacteria that had been isolated from compost.
\end{abstract}

Keywords: Petroleum Pollution, Soil Pollutants, Microbial Consortia, Hydrocarbons

\section{Background}

One of the major challenges created by petroleum industries is hydrocarbons that contaminate soil $(1,2)$. Slurry sequencing batch reactors (S-SBR) are an ex-situ bioremediation method (3) that are used to treat oil contaminated soils (4). Bioremediation rate in an S-SBR is higher than in situ or solid-phase systems; also, it has greater mass transfer rates $(3,5)$, and is more manageable, controllable, and predictable (6). Robles-Gonzalez et al. proposed the bioslurry reactor as a technology, which could be used for bioremediation of problematic sites (7).

The density of soil organisms is in the range of $10^{4}$ to $10^{7} \mathrm{CFU} /$ gram of soil (8). For favorable degradation, this density should not be lower than $10^{3}$ per gram of soil (9). Organism density lower than $10^{3} \mathrm{CFU}$ per gram of soil showed the probability of existence of toxic contaminants $(10,11)$.

Diesel oil is a complex compound (12) and contains ndodecane and n-hexadecane (8). N-hexadecane is released to the environment from gas stations, rubber manufac- turers, shale oil production, coal combustion, biomass and refuse combustion, and tobacco smoking $(13,14)$. Ndodecane is used as a solvent, distillation chaser, and scintillator component. It is used as a diluent for tributyl phosphate (TBP) in reprocessing plants. In the recent years, ndodecane has garnered attention as a possible surrogate for kerosene-based fuels, such as Jet-A, S-8 and other conventional aviation fuels (15).

Due to different oil compounds, n-alkanes with middle length chain $\left(\mathrm{C}_{10}-\mathrm{C}_{25}\right)$ are the favored substrate for organisms and are the most quickly degradable (9). In addition, longer chain alkanes $\left(\mathrm{C}_{25}-\mathrm{C}_{40}\right)$ are hydrophobic solids and therefore are hard to degrade due to their poor water solubility and bioaccessibility (16). In addition, in some studies $(8,17)$, n-hexadecane and n-dodecane were chosen as the model pollutants for diesel oil. Thus, in the present study, $\mathrm{n}$-alkanes with intermediate chain (n-hexadecane $\left(\mathrm{C}_{16} \mathrm{H}_{34}\right)$ and n-dodecane $\left.\left(\mathrm{C}_{12} \mathrm{H}_{26}\right)\right)$ were selected.

In different studies, degradation of n-hexadecane and n-dodecane from the soil was studied by pure $(8,18)$ 
and consortium cultures, including degradation of nhexadecane from the soil by pure and consortium cultures (19), aerobic degradation of n-hexadecane from soil by a pure culture (8), and the effect of co-metabolism on degradation of n-dodecane and n-hexadecane by a microbial consortium from the soil $(20,21)$.

Alkanes are important causes of soil contamination after oil spills. Isolation of microorganisms with the capacity of alkanes degradation is a cheap way for clean-up of the environment and solves problems related to oil industries. Iran is one of the biggest oil producers in the Persian Gulf region (22). In most areas, the contamination resulting from these products (gasoline, diesel and etc) is growing, and the contamination of soil and water resulting from these contaminants has been a problem. Thus, further studies are necessary to manage these contaminants.

\section{Objectives}

This study aimed at determining simultaneous bioremediation of $n$-hexadecane and $n$-dodecane from soil in an S-SBR by two types of bacterial consortium. Besides, it tried to compare the ability of two types of bacterial consortium in the bioremediation of oil hydrocarbons. Also, it attempted to determine variations of operating parameters, such as dissolved oxygen, temperature, $\mathrm{pH}$, and the number of active bacteria, during the bioreactor operating cycle.

\section{Methods}

In this study, all chemicals were purchased from the Merck Company (analytical grade, Germany).

The soil samples were collected at a depth of $30 \mathrm{~cm}$ from agricultural soil of Shiraz, Fars province, Iran (Table 1). Preparing the soil was continued by the following steps: (i) The soil was sifted with a 10-mesh $(2 \mathrm{~mm})$ strainer for screening the soil and reaching conformity. (ii) The soil was submerged in distilled water and autoclaved for 15 minutes at $121^{\circ} \mathrm{C}$. (iii) To sterilize, dry and reach a fixed weight, the soil was situated in the oven at $160^{\circ} \mathrm{C}$. (iv) The soil was sifted again with a 10-mesh $(2 \mathrm{~mm})$ strainer (23). (v) The soil was transmitted to a 1-L container. (vi) The soil was artificially contaminated with $1 \%$ concentration of $n$ dodecane and n-hexadecane. (vii) To the homogeneous dispersion of oil hydrocarbons, the soil was soaked in the solution (hexane, n-dodecane, and n-hexadecane solution) and regularly mixed at short intervals. (viii) To increase adsorption of oil hydrocarbons by the soil, the soil was placed at room temperature $\left(25^{\circ} \mathrm{C}\right)$ for a one-week period $(8,20,21)$.

\begin{tabular}{lc}
\hline Table 1. The Physicochemical Analysis of the Soil & \\
\hline Properties & Amounts \\
\hline $\mathbf{N}_{\mathbf{2}}$ (\%) & 0.09 \\
$\mathbf{C u}(\mathbf{p p m})$ & 11 \\
\hline $\mathbf{Z n}(\mathbf{p p m})$ & 12 \\
\hline $\mathbf{K}(\mathbf{p p m})$ & 186 \\
\hline Lime $(\%)$ & 44.85 \\
\hline EC (MS/cm) & 1.21 \\
\hline Clay (\%) & 20 \\
\hline Silt (\%) & 46.4 \\
\hline Sand (\%) & 33.6 \\
\hline Soil Texture & Loam \\
\hline Mn (ppm) & 20.4 \\
\hline Fe (ppm) & 10.2 \\
\hline P(ppm) & 10.1 \\
\hline Organic Carbon (\%) & 0.93 \\
\hline Humidity (\%) & 50 \\
\hline pH & 7.58 \\
\hline
\end{tabular}

For effective growth, microorganisms must have a supply of nutrients (24). Tap water was used to provide the nutrients. The essential nutrients composed of the following mineral salts: $\mathrm{NH}_{4} \mathrm{Cl}(2.5 \mathrm{~g} / \mathrm{L}), \mathrm{NaCl}(0.5 \mathrm{~g} / \mathrm{L}), \mathrm{MgSO}_{4}(0.3$ $\mathrm{g} / \mathrm{L}), \mathrm{FeCl}_{3} .6 \mathrm{H}_{2} \mathrm{O}(0.3 \mathrm{~g} / \mathrm{L}), \mathrm{CaCl}_{2}(0.01 \mathrm{~g} / \mathrm{L})$, and $\mathrm{MnCl}_{2} .4 \mathrm{H}_{2} \mathrm{O}$ $(0.01 \mathrm{~g} / \mathrm{L})$ added to tap water. Afterwards, the $\mathrm{pH}$ of the solution was adjusted to about seven. Then, the solution was autoclaved at $121^{\circ} \mathrm{C}$ for about 15 minutes. Finally, the solution was added to the bioreactor $(8,20,21)$.

For keeping the used bacteria in fresh form in the bioreactor, they were cultured weekly in mineral medium. To prepare the solid mineral medium, $1 \mathrm{~g} / \mathrm{L}$ of yeast extract (for better growth of bacteria) and $15 \mathrm{~g}$ of agar medium was added to the jar. The solution $\mathrm{pH}$ was adjusted to about seven. Then, the solution was added to the plates. For preparing the supply of carbon, $20 \mu \mathrm{L}$ of n-dodecane and n-hexadecane was poured on the plates uniformly. Finally, the plates were placed in the incubator at $37.5^{\circ} \mathrm{C}$ for 24 hours for bacterial growth $(8,20,21)$.

In this study, bacterial consortiums type A (Acinetobacter radioresistence, Bacillus subtilis and Pseudomonas aeruginosa) and type B (Ochrobactrum oryzae, Bacillus sp. and Sphingomonas yanoikuyae) was used. The bacterial consortium was isolated from oil contaminated soil and compost (8). For increasing the number of bacterial consortium, previously cultured bacteria in plates were re-cultured in nutrient broth medium. For bacterial growth, the solution was placed on the mixer in the incubator at $37.5^{\circ} \mathrm{C}$ for 24 hours. 
Then, the solution containing the bacteria was transferred to the test tubes. To isolate bacteria, the test tubes were centrifuged at $4000 \mathrm{rpm}$ for five minutes. To become certain of the homogeneous distribution of bacteria in the bioreactor, the optical density (OD) of the bacteria was adjusted at wavelength of $600 \mathrm{~nm}(\mathrm{OD}=1)$. Finally, isolated bacteria were added to the bioreactor $(2,20,21)$.

To measure the number of active bacteria in the bioreactor, the samples were taken from the bioreactor at various times. Then, the samples were cultured at three dilutions $\left(10^{-1}, 10^{-2}\right.$, and $\left.10^{-3}\right)$ on the nutrient agar medium. Next, considering the temperature of the bioreactor, the samples were placed in the incubator at various temperatures for 24 hours. After ensuring the growth of the bacteria, the colonies were counted by the colony counter. Finally, the number of active bacteria was reported based on $\mathrm{CFU} / \mathrm{mL}(20,21,25)$.

To analyze the residual of n-dodecane and nhexadecane, hydrocarbons were extracted from the soil through US.EPA method $355^{\circ} \mathrm{C}$. First, the samples were taken from deposited sediments after the sedimentation phase and dried at $37.5^{\circ} \mathrm{C}$. To remove moisture from the soil, 0.5 gram of the dried soil was combined with 0.5 gram anhydrous $\mathrm{Na}_{2} \mathrm{SO}_{4}$ (9). Four milliliters of hexane (as solvent) was added to the soil and mixed. The mixture was placed in an ultrasonic bath at $30^{\circ} \mathrm{C}$ for two minutes. Eventually, the upper portion of liquid of the container was transferred to test tubes. For better extraction, this process was repeated twice. Then, the test tubes were centrifuged at $4000 \mathrm{rpm}$ for five minutes to isolate the soil and the upper portion of the liquid. Then, $1 \mathrm{~mL}$ of the surface liquid was sampled. Finally, $2 \mu \mathrm{L}$ of the sample was injected to GC-FID $(20,21)$.

1, 2, 4-trichlorobenzene was used as an internal standard. CP-SILSCB (silica, USA) column (30 m length $\times 0.025$ $\mathrm{mm}$ id $\times 0.25 \mu \mathrm{m}$ film thickness) was used at a temperature program of $80^{\circ} \mathrm{C}$ for one minute, then increased to $125^{\circ} \mathrm{C}$ at $10^{\circ} \mathrm{C} /$ minute, held at $125^{\circ} \mathrm{C}$ for five minutes, then increased to $270^{\circ} \mathrm{C}$ at $40^{\circ} \mathrm{C} /$ minute, and held at $270^{\circ} \mathrm{C}$ for four minutes. The carrier gas was nitrogen and it was used at a constant flow rate of $2.7 \mathrm{~mL} /$ minute. The injector and detector temperatures were $210^{\circ} \mathrm{C}$ and $250^{\circ} \mathrm{C}$, respectively. Also, the detection limit of the GC-FID for n-dodecane and n-hexadecane was 132 and $166.5 \mathrm{mg} / \mathrm{Kg}$ dry weight soil, respectively (2). The chromatogram of n-dodecane and nhexadecane is presented in Figure 1.

In a glass bioreactor (total volume $=11 \mathrm{~L}$ and working volume $=5 \mathrm{~L}$ ), $250 \mathrm{~g}$ of oil hydrocarbons contaminated soil, the essential nutrients, and bacterial inoculation liquid was mixed with enough tap water (Figure 2). The samples were taken from both deposited sediments and upper liquid. In each cycle (74 hours), samples ( $8 \mathrm{~mL}$ ) were collected.
The first sample $\left(T_{0}\right)$ was taken one hour after start-up of the bioreactor (for being certain about the homogeneous distribution of the materials). Since the vapor pressures of n-dodecane and n-hexadecane were $20 \mathrm{~Pa}$ at $40^{\circ} \mathrm{C}$ and $100 \mathrm{~Pa}$ at $105.3^{\circ} \mathrm{C}$, respectively (26), sediment samples were placed in the incubator at $37.5^{\circ} \mathrm{C}$ to dry the sample. Besides, the researchers found that the residual of n-dodecane and n-hexadecane was extremely low when the samples were taken from the surface liquid; therefore, bioremediation was neglected in all of the surface liquid samples. A blank bioreactor simultaneously operated with the main bioreactor. The bioremediation of hydrocarbons was obtained by subtracting the total bioremediation of hydrocarbons in the main bioreactor from the remediation of hydrocarbons in the blank bioreactor.

In addition, variations in operating parameters, such as dissolved oxygen, temperature, $\mathrm{pH}$, and the number of active bacteria, were determined. For this purpose, samples were collected at zero, one, two, and three days. Operating parameters were measured using digital DO meter (Model parker, 1987), pH meter (Model 51- Japan), and thermometer $(20,21)$.

\section{Results}

\subsection{Variations of $p H$}

Table 2 shows the variations of $\mathrm{pH}$ during three days of bioreactor operating cycle. The $\mathrm{pH}$ ranges for consortium types A and B were 5.3 to 7.5 and 6.5 to 7.6, respectively. After three days, the $\mathrm{pH}$ values for consortium types $\mathrm{A}$ and $\mathrm{B}$ decreased to 2.2 and 1.1 , respectively.

\subsection{Dissolved Oxygen}

Table 2 provides the variations of dissolved oxygen during three days of bioreactor operating cycle. Based on the table, the dissolved oxygen ranges for consortium types $\mathrm{A}$ and B were 3 to $7 \mathrm{mg} / \mathrm{L}$ and 5 to $7.1 \mathrm{mg} / \mathrm{L}$, respectively. After three days, the dissolved oxygen in bioreactors $A$ and $B$ decreased to 4 and $2.1 \mathrm{mg} / \mathrm{L}$, respectively.

\subsection{Temperature}

Table 2 shows the variations of temperature during three days of bioreactor operating cycle. As shown in Table 2, the temperature ranges for bioreactors A and B were 25.5 to $29^{\circ} \mathrm{C}$ and 25.5 to $27^{\circ} \mathrm{C}$, respectively. After three days, the temperature for bioreactors $\mathrm{A}$ and $\mathrm{B}$ increased to $3.5^{\circ} \mathrm{C}$ and $1.5^{\circ} \mathrm{C}$, respectively. 


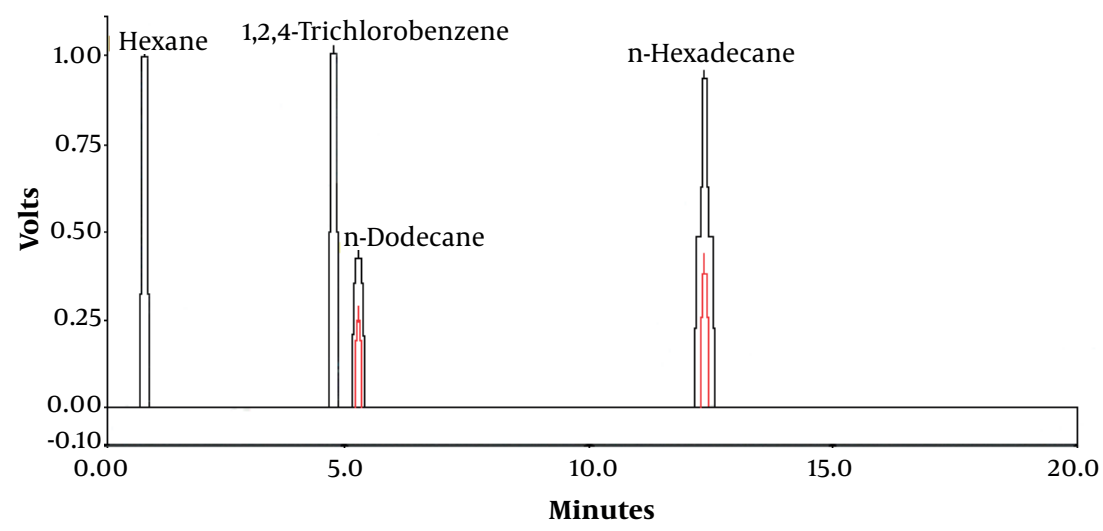

Figure 1. GC-FID chromatogram of n-dodecane and n-hexadecane before (black chromatogram) and after (red chromatogram) bioremediation

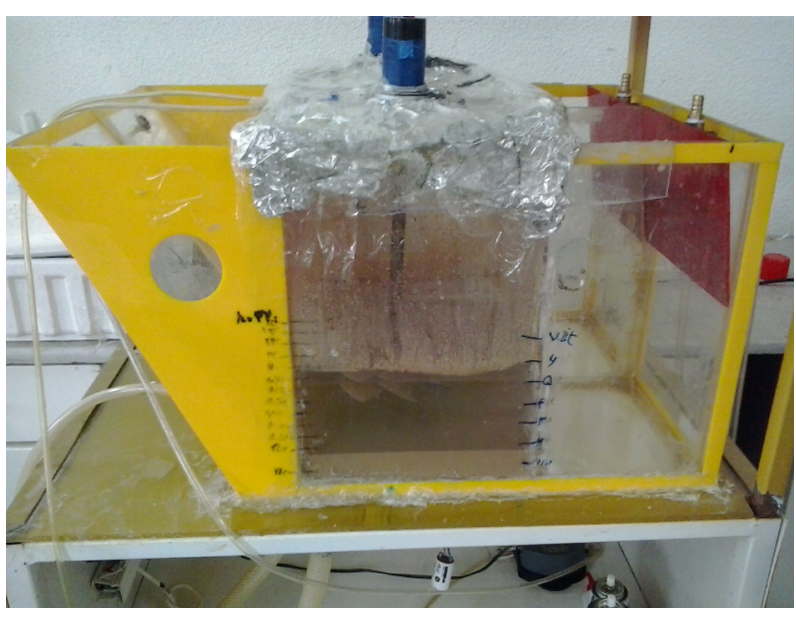

Figure 2. The slurry-sequencing batch reactor

\subsection{Density of Active Bacteria}

Table 2 shows the variations in density of active bacteria during three days of bioreactor operating cycle. Based on Table 2, the number of active bacteria ranges for bioreactors A and B, respectively, were $10^{4}$ to $10^{6}$ and $10^{4}$ to $10^{5}$ $\mathrm{CFU} / \mathrm{mL}$, respectively. After three days, the number of active bacteria for bioreactors A and B increased to $9 \times 10^{4}$ and $99 \times 10^{4} \mathrm{CFU} / \mathrm{mL}$, respectively.

\subsection{Bioremediation Study}

Table 3 shows simultaneous bioremediation of $\mathrm{n}$ hexadecane and n-dodecane by consortium types A and B. As depicted in Table 3, the minimum, average, and maximum simultaneous bioremediation of n-hexadecane by consortium type A was $6.64 \%, 12.79 \%$, and $17.61 \%$, whereas this was $4.65 \%$, $9.94 \%$, and $13.22 \%$ by consortium type B. Besides, the minimum, average, and maximum simultaneous bioremediation of n-dodecane by consortium type A were $10.97,18.77$, and 28.55 percent, while they were 8.9 , 14.71 , and 19.24 percent by consortium type $B$.

\section{Discussion}

Soil pH is important for enzyme activity $(9,27)$. The selection of $\mathrm{pH}$ depends on the organisms used for biodegradation (28). In the present study, after three days, $\mathrm{pH}$ values were decreased to 2.2 and 1.1 for consortium types A and B, respectively. The decrease in $\mathrm{pH}$ could attribute to the intermediate material produced by the consortium. In most studies, researchers reported that alkane degradation occurs at neutral $\mathrm{pH}$. The $\mathrm{pH}$ of soil according to soil composition and history ranged from around 2.5 to around 10 (29). Schauer pointed out in his review that the oxidation rates of hydrocarbons varied only slightly at $\mathrm{pH}$ values between 5 and 8, whereas oxidation and even toxicity of organic acids, microbial hydrocarbon metabolism products, were clearly dependent on $\mathrm{pH}$ (30). In another study, Rhodococcus erythropolis strain NTU-1 was incubated in fed-batch bioreactor for bioremediation of diesel and petroleum. After six days of incubation with diesel, the $\mathrm{pH}$ decreased from 7 to 4.3, while in incubations with petroleum, the $\mathrm{pH}$ decreased from 7 to 5 . In addition, $\mathrm{pH}$ changes were related to cell growth (31). It is known that $\mathrm{pH}$ changes of the medium affect the net charge of polysaccharides, phosphates, and amino groups on a cell's surface (32). Also, results of the study of Dastgheib et al. showed that biodegradation of polycyclic aromatic hydrocarbons with Alcanivorax dieselolei strain QTET was extremely unstable at high $\mathrm{pH}$. The range of its $\mathrm{pH}$ tolerance was limited ( $\mathrm{pH} 6$ to 8 ) and its optimum growth was at neutral $\mathrm{pH}$ (33). 


\begin{tabular}{|c|c|c|c|c|}
\hline \multirow{2}{*}{ Consortium Type } & \multicolumn{4}{|c|}{ Time (Days) } \\
\hline & Zero Day & First Day & Two Days & Three Days \\
\hline \multicolumn{5}{|l|}{ pH } \\
\hline A & 7.5 & 6.5 & 6 & 5.3 \\
\hline $\mathrm{B}$ & 7.6 & 7.2 & 6.7 & 6.5 \\
\hline \multicolumn{5}{|l|}{ Dissolved oxygen $(\mathrm{mg} / \mathrm{L})$} \\
\hline A & 7 & 6.2 & 4.6 & 3 \\
\hline B & 7.1 & 6.7 & 5.9 & 5 \\
\hline \multicolumn{5}{|l|}{ Temperature $\left({ }^{\circ} \mathrm{C}\right)$} \\
\hline A & 25.5 & 26.5 & 27.3 & 29 \\
\hline $\mathrm{B}$ & 25.5 & 25.9 & 26.7 & 27 \\
\hline \multicolumn{5}{|l|}{ Number of active bacteria (CFU/mL) } \\
\hline A & $1 \times 10^{4}$ & $3 \times 10^{4}$ & $5 \times 10^{5}$ & $1 \times 10^{6}$ \\
\hline B & $1 \times 10^{4}$ & $2 \times 10^{4}$ & $7 \times 10^{4}$ & $1 \times 10^{5}$ \\
\hline \multirow{2}{*}{ Type of Consortium } & \multicolumn{4}{|c|}{ Simultaneous Bioremediation (\%) } \\
\hline & Zero Day & First Day & Two Days & Three Days \\
\hline N-hexadecane with consortium type A & 0 & 6.6 & 14.1 & 17.6 \\
\hline $\mathrm{N}$-hexadecane with consortium type B & 0 & 4.6 & 11.9 & 13.2 \\
\hline $\mathrm{N}$-dodecane with consortium type A & 0 & 10.9 & 16.7 & 28.5 \\
\hline N-dodecane with consortium type B & 0 & 8.9 & 15.9 & 19.2 \\
\hline
\end{tabular}

Dissolved oxygen is essential for biodegradation (23). Because there is a high concentration of hydrogen and carbon, yet small amounts of oxygen in petroleum compounds (34), 3 to $4 \mathrm{~mL}$ of dissolved oxygen are required to oxidize $1 \mathrm{~mL}$ of hydrocarbons to $\mathrm{CO}_{2}$ and $\mathrm{H}_{2} \mathrm{O}$ (35). For aerobic bacteria, stoichiometrically, $3.1 \mathrm{mg} / \mathrm{mL}$ of oxygen is needed for the biodegradation of $1 \mathrm{mg} / \mathrm{mL}$ of hydrocarbons, regardless of the total mass of bacteria (36). In this study, after three days, the dissolved oxygen for consortium types A and B decreased to 4 and $2.1 \mathrm{mg} / \mathrm{L}$, respectively. In agreement with other reports, such as that of Venkata Mohan et al. (5) and Juneson et al. (37), the activity of microorganisms and the rate of oxygen uptake increased.

Temperature has a noticeable effect on the capability of microorganisms for degradation of petroleum hydrocarbons. In addition, with rising temperature, solubility of oxygen is reduced, and consequently metabolic activity of aerobic microorganisms is also reduced. Most oil-degrading organisms are active in the meso-thermal ranges $\left(20^{\circ} \mathrm{C}\right.$ to $\left.35^{\circ} \mathrm{C}\right)$ and have the best degradation rates at these temperatures (35). Some exceptions exist; for example, Rueter et al. (38) described a slightly ther- mophilic anaerobic strain (TD3) that degrades alkane under sulphate-reducing conditions; Klug and Markovetz (39) reported on thermophilic bacteria, which can degrade n-tetradecane. Also, industrial alkane degradation at high temperatures (e.g. $65^{\circ} \mathrm{C}$ to $70{ }^{\circ} \mathrm{C}$ ) has been reported (40). Based on the current results, the temperature for consortium types $\mathrm{A}$ and $\mathrm{B}$ increased to $3.5^{\circ} \mathrm{C}$ and $1.5^{\circ} \mathrm{C}$, respectively after three days. There was a direct relationship between temperature and activity of microorganisms, thus microorganisms activity increases with increasing temperature and conversely (41).

The findings of this study indicate that After three days, the number of active bacteria for consortium types $A$ and B increased to $9 \times 10^{4}$ and $99 \times 10^{4} \mathrm{CFU} / \mathrm{mL}$, respectively (Table 2). Genthner et al. reported that almost all PAHs are degraded at $15^{\circ} \mathrm{C}$ and at an oxygen level of $4 \mathrm{ppm}$, and at $40^{\circ} \mathrm{C}$ most PAHs are degraded at 0 ppm oxygen level (42). The increase in the number of active bacteria can be due to further adaptation of bacteria to the bioreactor and greater growth. In addition, it can concluded that bacteria type A were more compatible with oil hydrocarbons than type B. Genthner et al. reported that almost all PAHs are 
degraded at $15^{\circ} \mathrm{C}$ and at an oxygen level of $4 \mathrm{ppm}$, and at $40^{\circ} \mathrm{C}$ most PAHs are degraded at $0 \mathrm{ppm}$ oxygen level (42). A few researchers showed that the number of active bacteria was $5.25 \times 10^{5}, 1.76 \times 10^{6}$ and $5.11 \times 10^{5}$ cells per $\mathrm{mL}$ of soil. Besides, they showed that these species can degrade n-hexadecane up to a concentration of 120 ppm and a consortium of species could degrade n-hexadecane faster than they do separately (43).

Maximum simultaneous bioremediation of $n$ hexadecane by consortium type A and B was 17.61 and 13.22 percent. In addition, maximum simultaneous bioremediation of n-dodecane by consortium type A and B was 28.55 and 19.24 percent (Table 3). On the other hand, the bioremediation of n-hexadecane by consortium type A on days one, two, and three was 1.99, 2.17, and 4.39 percent greater than type $B$. The bioremediations of n-dodecane by consortium type A on days one, two, and three was $4.33,2.67$, and 10.94 percent greater than type B (Table 3 ). Based on the results, it can be concluded that consortium type A had better adaptation with bioreactor conditions than type A. In addition, bioremediation of n-dodecane during the three days of operation cycle was greater than n-hexadecane (Table 3). Considering the molecular formula of n-dodecane $\left(\mathrm{C}_{12} \mathrm{H}_{26}\right)$, with lower carbon and hydrogen than n-hexadecane $\left(\mathrm{C}_{16} \mathrm{H}_{34}\right)$, it can be suggested that the bacteria had a higher potential for bioremediation of n-dodecane than n-hexadecane. In Lopez et al.'s study, the findings showed that bioremediation was significantly influenced by different bioavailability (44). Also, Sun et al. (45) studied the simultaneous bioremediation of n-hexadecane and phenol. They found the strains were capable of simultaneous bioremediation of phenol and n-hexadecane in the mineral medium. However, the strains preferred phenol to n-hexadecane. Also, the coexistence of phenol and n-hexadecane was outperformed in the growth of strains in comparison with when they were used individually (45). A simulation test was conducted to study biodegradation of aromatic hydrocarbons (phenanthrene and anthracene) and aliphatic hydrocarbon (n-hexadecane) by native microorganisms, when the soil contained the test hydrocarbons individually or in coexistence. The results showed that coexistence of phenanthrene and n-hexadecane could serve as a co-metabolic substrate and promote biodegradation of phenanthrene, lessening the half-life of phenanthrene by $44 \%$ in comparison with when phenanthrene existed individually (46).

\subsection{Conclusions}

The results showed that the maximum simultaneous bioremediation of n-hexadecane and n-dodecane by consortium type A was 17.61 and 28.55 percent, respectively. In addition, the maximum simultaneous bioremediation of $\mathrm{n}$-hexadecane and n-dodecane by consortium type B was 13.22 and 19.24 percent, respectively. Bioremediation of $n$ hexadecane and n-dodecane by bacterial consortium Type A (isolated from contaminated soil with oil) was significantly greater than type B (isolated from compost). In general, the bioremediation of n-dodecane during three days of the reactor's running cycle was greater than nhexadecane. The findings of this study showed the simultaneous bioremediation of n-hexadecane and n-dodecane in an S-SBR, using two types of bacterial consortium (type A and B) during a three-day period, was relatively satisfactory.

\section{Acknowledgments}

The authors would like to thank the deputy of research and technology of Shiraz University of medical sciences for their financial support of the research project (No: 92 - 6794). The authors also thank Dr. Reza Kafipour at the language department of Shiraz University of Medical Sciences for professional language editing of the manuscript.

\section{Footnotes}

Authors' Contribution: The overall implementation of this study including design, experiments, data analysis, and manuscript preparation were the results of the corresponding author's efforts. All authors made an extensive contribution to the review and finalization of this manuscript. All authors read and approved the final manuscript.

Conflict of Interests: The authors declare that they had no competing interests.

Funding/Support: Vice-chancellor of Shiraz University of Medical Sciences financially supported this study.

\section{References}

1. Joseph PJ, Joseph A. Microbial enhanced separation of oil from a petroleum refinery sludge. J Hazard Mater. 2009;161(1):522-5. doi: 10.1016/j.jhazmat.2008.03.131. [PubMed: 18468790].

2. Dehghani M, Taatizadeh SB, Samaei MR. Biodegradation of nhexadecane in acinetobacter radioresistens liquid culture. Health Scope. 2013;2(3):162-7. doi: 10.17795/jhealthscope-14262.

3. Prasanna D, Venkata Mohan S, Purushotham Reddy B, Sarma PN. Bioremediation of anthracene contaminated soil in bio-slurry phase reactor operated in periodic discontinuous batch mode. $J \mathrm{Haz}$ ard Mater. 2008;153(1-2):244-51. doi: 10.1016/j.jhazmat.2007.08.063. [PubMed: 17923291].

4. Boopathy R. Factors limiting bioremediation technologies. Bioresource Technology. 2000;74(1):63-7. doi: 10.1016/s0960-8524(99)001443. 
5. Venkata Mohan S, Kisa T, Ohkuma T, Kanaly RA, Shimizu Y. Bioremediation technologies for treatment of PAH-contaminated soil and strategies to enhance process efficiency. Rev Environ Sci Biotechnol. 2006;5(4):347-74. doi: 10.1007/s11157-006-0004-1.

6. Vidali M. Bioremediation. An overview. Pure Appl Chem. 2001;73(7):1163-72. doi: 10.1351/pac200173071163.

7. Robles-Gonzalez IV, Fava F, Poggi-Varaldo HM. A review on slurry bioreactors for bioremediation of soils and sediments. Microb Cell Fact. 2008;7:5. doi:10.1186/1475-2859-7-5. [PubMed:18312630]. [PubMed Central: PMC2292675].

8. Samaei MR, Mortazavi SB, Bakhshi B, Jonidi Jafari A. Isolation, genetic identification, and degradation characteristics of n-Hexadecane degrading bacteria from tropical areas in Iran. Freseb Environ Bull. 2013;22(4):1304-12.

9. Samaei MR, Mortazavi SB, Jonidi Jafari A, Bakhshi B. Isolation, biodegradation ability, and molecular detection of n-Hexadecane degrading bacteria from compost. Antalya/Turkey; 2014.

10. Margesin R, Labbe D, Schinner F, Greer CW, Whyte LG. Characterization of hydrocarbon-degrading microbial populations in contaminated and pristine Alpine soils. Appl Environ Microbiol. 2003;69(6):3085-92. [PubMed: 12788702]. [PubMed Central: PMC161509].

11. Pawar RM. The effect of soil pH on degradation of polycyclic aromatic hydrocarbons. University of Hertfordshire; 2012.

12. Dehghani M, Shahsavani E, Farzadkia M, Samaei MR. Optimizing photo-Fenton like process for the removal of diesel fuel from the aqueous phase. J Environ Health Sci Eng. 2014;12:87. doi: 10.1186/2052336X-12-87. [PubMed: 24955242]. [PubMed Central: PMC4045957].

13. Hawthorne SB, Sievers RE. Emission of organic air pollutants from shale oil wastewaters. Environ Sci Technol. 1984;18(6):483-90. doi: 10.1021/es00124a016. [PubMed: 22247953].

14. Dannecker W, Au M, Stechmann H. Substance load in rainwater runoff from different streets in Hamburg. Sci Total Environ. 1990;93:385-92. [PubMed: 2360021].

15. Rydberg J. Solvent extraction principles and practice, revised and expanded. 2, revised ed. CRC Press; 2004. doi: 10.1201/9780203021460.

16. Maletic SP, Dalmacija BD, Roncevic SD, Agbaba JR, Perovic SD. Impact of hydrocarbon type, concentration and weathering on its biodegradability in soil. J Environ Sci Health A Tox Hazard Subst Environ Eng. 2011;46(10):1042-9. doi: 10.1080/10934529.2011.590380. [PubMed 21806450].

17. Noordman WH, Wachter JHJ, de Boer GJ, Janssen DB. The enhancement by surfactants of hexadecane degradation by Pseudomonas aeruginosa varies with substrate availability.JBiotech. 2002;94(2):195212. doi: 10.1016/s0168-1656(01)00405-9.

18. Samaei MR, Mortazavi SB, Bakhshi B, Jonidi Jafari A. Isolation and Characterization of bacteria degrading n-Hexadecane from soil. International Conference on Biological and Life Sciences Singapore. 2012. p. $132-5$.

19. Tzintzun-Camacho O, Loera O, Ramírez-Saad HC, Gutiérrez-Rojas M. Comparison of mechanisms of hexadecane uptake among pure and mixed cultures derived from a bacterial consortium. Int Biodeter Biodegr. 2012;70:1-7. doi:10.1016/j.ibiod.2012.01.009.

20. Nozari M, Samaei MR, Dehghani M. Investigation of the effect of cometabolism on removal of dodecane by microbial consortium from soil in a slurry sequencing bioreactor.J Bioremed Biodeg. 2014;5(7):1-9.

21. Nozari M, Samaei MR, Dehghani M. The effect of co-metabolism on removal of hexadecane by microbial consortium from soil in a slurry sequencing batch reactor. J Health Sci Surveillance Sys. 2014;2(3):113-24.

22. Birol F. World energy outlook 2010. 1. International Energy Agency; 2010. p. 1-23.

23. Jorfi S, Samaei MR, Darvishi Cheshmeh Soltani R, Talaie Khozani A, Ahmadi M, Barzegar G, et al. Enhancement of the bioremediation of pyrene-contaminated soils using a hematite nanoparticle-based modified fenton oxidation in a sequenced approach. Soil Sediment Contam. 2017;26(2):141-56. doi:10.1080/15320383.2017.1255875.
24. Rostami S, Azhdarpoor A, Rostami M, Samaei MR. The effects of simultaneous application of plant growth regulators and bioaugmentation on improvement of phytoremediation of pyrene contaminated soils. Chemosphere. 2016;161:219-23. doi: 10.1016/j.chemosphere.2016.07.026. [PubMed: 27434251]

25. Ansari Shiri M, Dehghani M, Samaei MR. Isolation of atrazine degrading bacteria in semi-salinity medium. J Health Sci Surveillance Sys. 2016;4(3):121-8.

26. Maeda N, Israelachvili JN, Kohonen MM. Evaporation and instabilities of microscopic capillary bridges. Proc Natl Acad Sci U S A. 2003;100(3):803-8. doi: 10.1073/pnas.0234283100. [PubMed: 12538868]. [PubMed Central: PMC298682]

27. Tang J, Lu X, Sun Q, Zhu W. Aging effect of petroleum hydrocarbons in soil under different attenuation conditions. Agric Ecosyst Environ. 2012;149:109-17. doi:10.1016/j.agee.2011.12.020.

28. Bonomo RP, Cennamo G, Purrello R, Santoro AM, Zappala R. Comparison of three fungal laccases from Rigidoporus lignosus and Pleurotus ostreatus: correlation between conformation changes and catalytic activity. J Inorg Biochem. 2001;83(1):67-75. doi: 10.1016/s01620134(00)00130-6.

29. Berthe-Corti L, Fetzner S. Bacterial metabolism of n-alkanes and ammonia under oxic, suboxic and anoxic conditions. Eng Life Sci. 2002;22(3-4):299-336. doi: 10.1002/1521-3846(200207)22:3/4<299::aidabio299>3.0.co;2-f.

30. Schauer F. [Degradation and utilization of mineral oil constituents by microorganisms]. 11. Bodden: University of Greifswald; 2001. German.

31. Liu CW, Liu HS. Rhodococcus erythropolis strain NTU-1 efficiently degrades and traps diesel and crude oil in batch and fed-batch bioreactors. Process Biochem. 2011;46(1):202-9. doi: 10.1016/j.procbio.2010.08.008.

32. Poortinga AT, Bos R, Norde W, Busscher HJ. Electric double layer interactions in bacterial adhesion to surfaces. Surf Sci Rep. 2002;47(1):1-32. doi: 10.1016/s0167-5729(02)00032-8.

33. Dastgheib SM, Amoozegar MA, Khajeh K, Shavandi M, Ventosa A. Biodegradation of polycyclic aromatic hydrocarbons by a halophilic microbial consortium. Appl Microbiol Biotechnol. 2012;95(3):789-98. doi: 10.1007/s00253-011-3706-4. [PubMed: 22086071]

34. Rockne KJ, Strand SE. Biodegradation of bicyclic and polycyclic aromatic hydrocarbons in anaerobic enrichments. Environ Sci Technol. 1998;32(24):3962-7.

35. Shallu S, Hardik P, Jaroli DP. Factors affecting the rate of biodegradation of polyaromatic hydrocarbons. Int J Pure App Biosci. 2014;2(3):185202.

36. Curtis F, Lammey J. Intrinsic remediation of a diesel fuel plume in Goose Bay, Labrador, Canada. Environ Pollut. 1998;103(2-3):203-10. doi: 10.1016/s0269-7491(98)00126-2.

37. Juneson C, Ward OP, Singh A. Biodegradation of bis (2-ethylhexyl) phthalate in a soil slurry-sequencing batch reactor. Process Biochem. 2001;37(3):305-13. doi:10.1016/s0032-9592(01)00196-0.

38. Rueter P, Rabus R, Wilkes H, Aeckersberg F, Rainey FA, Jannasch $\mathrm{HW}$, et al. Anaerobic oxidation of hydrocarbons in crude oil by new types of sulphate-reducing bacteria. Nature. 1994;372(6505):455-8. doi: 10.1038/372455a0. [PubMed: 7984238].

39. Klug MJ, Markovetz AJ. Thermophilic bacterium isolated on ntetradecane. Nature. 1967;215(5105):1082-3. [PubMed: 6061797].

40. Sukatsch DA, Johnson MJ. Bacterial cell production from hexadecane at high temperatures. Appl Microbiol.1972;23(3):543-6. [PubMed: 5021971]. [PubMed Central: PMC380384].

41. Ratkowsky DA, Olley J, McMeekin TA, Ball A. Relationship between temperature and growth rate of bacterial cultures. J Bacteriol. 1982;149(1):1-5. [PubMed: 7054139]. [PubMed Central: PMC216584].

42. Genthner B, Townsend GT, Lantz SE, Mueller JG. Persistence of polycyclic aromatic hydrocarbon components of creosote under anaerobic enrichment conditions. Archives of Environmental Contamination and Toxicology. 1997;32(1):99-105. doi: 10.1007/s002449900160. 
43. Ahmed AM, Naif AH, Salem AD. Hexadecane degradation by bacterial strains isolated from contaminated soils. Afr J Biotechnol. 2010;9(44):7487-94. doi: 10.5897/ajb10.638.

44. Lopez Z, Vila J, Ortega-Calvo JJ, Grifoll M. Simultaneous biodegradation of creosote-polycyclic aromatic hydrocarbons by a pyrenedegrading Mycobacterium. Appl Microbiol Biotechnol. 2008;78(1):16572. doi: 10.1007/s00253-007-1284-2. [PubMed: 18074131].
45. Sun JQ, Xu L, Tang YQ, Chen FM, Wu XL. Simultaneous degradation of phenol and n-hexadecane by Acinetobacter strains. Bioresour Technol. 2012;123:664-8. doi: 10.1016/j.biortech.2012.06.072. [PubMed: 22939600].

46. Zhao XX, Zhao HM, Quan X, Chen S, Zhao YZ. Biodegradation of phenanthrene, anthracene and n-hexadecane in petroleumcontaminated soil. Chinese J Eco. 2009;3:456-60. 